\title{
Specific Identification of Coconut Tinangaja Viroid for Differential Field Diagnosis of Viroids in Coconut Palm
}

\author{
R. A. J. Hodgson, G. C. Wall, and J. W. Randles
}

First and third authors: Department of Crop Protection, University of Adelaide, Waite Campus, Glen Osmond, SA 5064, Australia; and second author: Unibetsedat Guaiian, College of Agriculture and Life Science, Agriculture Experiment Station, Mangilao, Guam 96923. Accepted for publication 21 March 1998.

\begin{abstract}
Hodgson, R. A. J., Wall, G. C., and Randles, J. W. 1998. Specific identification of coconut tinangaja viroid for differential field diagnosis of viroids in coconut palm. Phytopathology 88:774-781.

Tinangaja is a widespread lethal disease of putative viroid etiology affecting coconut palm on the island of Guam. Determination of its distribution and mode of spread requires a simple and reliable diagnostic procedure that is specific for the associated coconut tinangaja viroid (CTiVd). A method of extracting tissue followed by analytical agarose gel electrophoresis for CTiVd detection has been developed and used to identify the viroid in leaf samples of suspect symptomatic palms growing in the field. Two-dimensional polyacrylamide gel electrophoresis showed

els of viroid below the threshold of detection by agarose gel electrophoresis was achieved either by diagnostic oligonucleotide-probe (DOP) hybridization assay or by reverse-transcription polymerase chain reaction (RT-PCR) with the oligonucleotide probe as one of the two PCR primers. RT-PCR was not substantially more sensitive than DOP-hybridization assay. This procedure also was applicable to coconut cadang-cadang viroid (CCCVd), and oligonucleotide probes designed to be specific for either $\mathrm{CTiVd}$ or CCCVd distinguished between these two viroids in coconut leaf extracts. This strategy provides a rapid and specific indexing procedure for the two characterized viroids of coconut palm and will be applicable to further studies on the viroid-like sequences previously reported in tropical monocotyledons.
\end{abstract} that the viroid band contained circular molecules that are typical for viroids. Confirmation of the identity of CTiVd and detection of low lev-
Additional keywords: viroid indexing.
Tinangaja is a lethal disease of coconut palm on the island of Guam and was first described in $1917(1,19)$. The disease resembles cadang-cadang disease of coconut palm, which occurs in the Philippines and is caused by the coconut cadang-cadang viroid (CCCVd) $(7,12-14)$. Coconut tinangaja viroid (CTiVd) is associated with tinangaja disease $(2,10)$ and has a monomer size of 254 nucleotides (nt), which is $8 \mathrm{nt}$ larger than CCCVd. The two viroids share about $65 \%$ overall sequence identity (11). Although inoculation of coconuts with $\mathrm{CTiVd}$ has yet to be done to confirm that it is the causal agent of tinangaja, its association with the disease provides a molecular marker for studies of disease distribution and spread. Since the early epidemics of tinangaja were reported (2), coconut groves have been neglected on Guam, and tinangaja disease has not been considered economically important. However, there is again high incidence of tinangaja in some areas of Guam (18), and it is necessary to determine the epidemiology of the disease as a basis for developing appropriate control measures. For surveys of disease incidence and spread, specific, rapid, sensitive, and economical diagnostic methods are needed.

The aim of this work was to develop a procedure suitable for mapping the distribution of CTiVd in the field. We evaluated the relationship between disease symptoms and the presence of CTiVd in leaf nucleic acid extract. Viroid presence was detected in palms showing severe symptoms by an initial screening of nucleic acid using simple agarose gel fractionation. Viroid presence was verified in these samples and in samples from palms showing little or no tinangaja disease symptoms by a molecular hybridization assay in which diagnostic oligonucleotide probes (DOPs) to CTiVd were used.

Corresponding author: R. Hodgson

E-mail address: rhodgson@waite.adelaide.edu.au

Publication no. P-1998-0527-01R

(C) 1998 The American Phytopathological Society

\section{MATERIALS AND METHODS}

Sample collection. A standardized data sheet was used to describe each palm sampled at the time of collection. Leaflet samples of about $100 \mathrm{~g}$ were harvested from the lower crown of 15 coconut (Cocos nucifera L.) palms near the University of Guam. Samples were sealed in plastic bags and maintained at between 15 and $30^{\circ} \mathrm{C}$ and sent by air-freight courier to the Waite Campus, Glen Osmond, Australia, within 2 days of collection. Several 0.5-g subsamples were removed for immediate extraction, and all remaining material was stored at $-20^{\circ} \mathrm{C}$.

Extraction. Nucleic acids enriched for viroids were extracted by a modification of a short coconut leaf extraction procedure (16). A 0.5 -g sample of tissue was placed in a thick-walled plastic bag $(75 \times 140 \mathrm{~mm})$ with $2 \mathrm{ml}$ of sterile NETM buffer $(2 \mathrm{M} \mathrm{NaCl}$, $100 \mathrm{mM}$ sodium acetate, $10 \mathrm{mM}$ EDTA, $50 \mathrm{mM}$ Tris- $\mathrm{HCl}[\mathrm{pH}$ 7.5], $0.25 \%$ [ $\mathrm{vol} / \mathrm{vol}]$ 2-mercaptoethanol). The sample was crushed by hammering, and $800 \mu \mathrm{l}$ was removed and added to $40 \mu \mathrm{l}$ of $20 \%$ (wt/vol) sodium dodecyl sulfate (SDS) solution in a $1.5-\mathrm{ml}$ microfuge tube. The solution was mixed for $30 \mathrm{~min}$ at $25^{\circ} \mathrm{C}$ before addition of $750 \mu \mathrm{l}$ of phenol/chloroform/isoamyl alcohol (25:24:1), followed by vortexing for $20 \mathrm{~s}$ and centrifugation $(10,000 \times g$ for $15 \mathrm{~min})$ to separate the phases. An aliquot of $700 \mu \mathrm{l}$ from the upper aqueous phase was removed, and nucleic acids were precipitated by adding 1 volume of isopropanol. The pellet was washed with $70 \%$ ethanol, air-dried, and dissolved in $50 \mu \mathrm{l}$ of sterile diethylpyrocarbonate-treated water.

Gel electrophoresis. Nucleic acid samples were fractionated on $2.5 \%$ (wt/vol) agarose mini-gels (SeaKem LE, FMC Corporation, Rockland, ME) buffered with $0.5 \times$ TAE $(20 \mathrm{mM}$ Tris-acetate [pH 7.6], $0.5 \mathrm{mM}$ EDTA) containing $0.5 \mu \mathrm{g}$ of ethidium bromide per $\mathrm{ml}$. Samples were run at $100 \mathrm{~V}$ for $\approx 45 \mathrm{~min}$, equivalent to 50 -mm migration of the bromophenol blue marker dye. Gels were exposed to transmitted UV light $(254 \mathrm{~nm})$ and photographed through a 540-nm orange filter with Polaroid 667 ISO 3000 film (Polaroid 
UK Ltd., Hertfordshire, England). Electrophoresis in $20 \%$ polyacrylamide gels was as previously described (6).

Two-dimensional polyacrylamide gel electrophoresis (2-D PAGE). The circular form of CTiVd was identified in extracts of coconut palm by 2-D PAGE following the procedure of Feldstein et al. (4) with slight modification. Glass plates were $3 \mathrm{~mm}$ thick: one plate was $165 \mathrm{~mm}$ square; the other plate was $170 \mathrm{~mm}$ square. The gel was clamped to a Bio-Rad model 220 Dual Vertical Slab Gel apparatus (Bio-Rad Laboratories, Hercules, CA), preheated to $50^{\circ} \mathrm{C}$ by circulating water from a thermostatted water bath to the central chamber of the apparatus, and prerun at $45 \mathrm{~mA}$ per gel (range 330 to $380 \mathrm{~V}$ ) for $30 \mathrm{~min}$. The sample $(40 \mu \mathrm{l})$ in TBE loading buffer ( $89 \mathrm{mM}$ Tris, $89 \mathrm{mM}$ boric acid, $2 \mathrm{mM}$ EDTA, $10 \%$ [vol/vol] glycerol, $0.25 \%$ [wt/vol] xylene cyanol [pH 8.3]) was loaded into the well of the 39:1 (acrylamide/bis-acrylamide) gel component and electrophoresed until the dye had migrated to the bottom. The plates were unclamped, the spacers removed and placed on the other two sides of the plate, and, after rotating $90^{\circ}$, the plate was reclamped so the track of the first dimension now ran across the top of the gel. Electrophoresis in the second dimension was in the 38:2 (acrylamide/bis-acrylamide) gel at $50^{\circ} \mathrm{C}$ until the dye was within $10 \mathrm{~mm}$ of the bottom of the gel. The gel was stained with $1 \mu \mathrm{g}$ of ethidium bromide per $\mathrm{ml}$ in sterile water and observed under UV illumination at $302 \mathrm{~nm}$.

Nucleic acid blotting. RNA transfer from agarose gels to nylon membrane (Zeta Probe, Bio-Rad) was by capillary blotting, using a standard Northern blot procedure (17), except that the transfer solution was $20 \mathrm{mM} \mathrm{NaOH}$. Transferred nucleic acid was crosslinked to wet membranes by UV irradiation (125 mJ; GS Gene Linker, Bio-Rad). For dot blots, $2 \mu \mathrm{l}$ of each nucleic acid sample was applied directly to the nylon membrane and cross-linked by UV irradiation. Transfer of nucleic acid from polyacrylamide gels by electrophoretic blotting was done as previously described (6).

Probe preparation and purification. Three antisense DOPs were used to detect CTiVd. These probes were complementary to the viroid across either residues 101 to 71 (D1-2; 5'-ACCAGGTACGCTCCCTACCTCGGTTGCTAGG-3'), 131 to 102 (D2-2; 5'-GACGAAGCCCAACCAGCACGAATCGGCGAC-3'), or 239 to 207 (D3-2; 5'-ACTCGAGCTTTTATTACACAGGGCGCTGCAAAG-3'). Probes were 5'-end-labeled in a reaction mix that included $50 \mathrm{pmol}$ oligonucleotide, reaction buffer $(50 \mathrm{mM}$ Tris- $\mathrm{HCl}$ [pH 7.5], $10 \mathrm{mM} \mathrm{MgCl}_{2}, 5 \mathrm{mM}$ dithiothreitol, $100 \mu \mathrm{M}$ spermidine, $100 \mu \mathrm{M}$ EDTA), $\gamma^{-32} \mathrm{P}$ ATP $(555 \mathrm{kBq}, 148 \mathrm{TBq} / \mathrm{mmol}$; Bresatec, Adelaide, Australia), 4.5 units of polynucleotide kinase (Bresatec), and water to a final volume of $15 \mu \mathrm{l}$. After incubation at $37^{\circ} \mathrm{C}$ for $60 \mathrm{~min}$, an equal volume of formamide loading dye (80\% [vol/vol] formamide, $10 \mathrm{mM}$ EDTA, $0.25 \%$ [wt/vol] bromophenol blue, $0.25 \%$ [wt/vol] xylene cyanol) was added, the sample was heated at $80^{\circ} \mathrm{C}$ for $90 \mathrm{~s}$, immediately chilled on ice, loaded on a $400-\mathrm{mm}$ denaturing gel $(20 \%$ [wt/vol] polyacrylamide [acrylamide/bis-acrylamide, 19:1], $7 \mathrm{M}$ urea, in TBE), and fractionated for $2 \mathrm{~h}$ at $25 \mathrm{~mA}$. The end-labeled probe was detected by autoradiography, the gel piece with full-length DOP was excised, and the probe was eluted into $800 \mu \mathrm{l}$ of $0.1 \mathrm{mM}$ EDTA at $37^{\circ} \mathrm{C}$. The solution was removed, dried under vacuum, and dissolved in $200 \mu \mathrm{l}$ of water, and the probe was precipitated in the presence of $0.3 \mathrm{M}$ sodium acetate and 2.5 volumes of cold ethanol/acetone (1:1) and resuspended in water to give $500 \mathrm{cps} / \mu \mathrm{l}$. Preparation of the fulllength CCCVd cRNA probe was as previously described (6).

Membrane-based nucleic acid hybridization. The DOP-hybridization procedure (8) was based on the principles outlined by Randles et al. (15). Membranes for Northern blot analysis were stacked with alternating sheets of fine nylon gauze and placed inside the bottles of a Hybaid (Teddington, England) mini hybridization oven. Membranes were prewashed at $37^{\circ} \mathrm{C}$ for $2 \mathrm{~h}$ in $0.1 \times$ $\mathrm{SSC}(1 \times \mathrm{SSC}$ is $150 \mathrm{mM} \mathrm{NaCl}, 15 \mathrm{mM}$ sodium citrate, $\mathrm{pH} \mathrm{7.0)}$ containing $0.5 \%$ SDS. Prehybridization was in hybridization buffer (5× SSC, $20 \mathrm{mM} \mathrm{NaH}{ }_{2} \mathrm{PO}_{4}$ [pH 7.0], 2.5\% [wt/vol] SDS, 5×
Denhardt's solution, $100 \mu \mathrm{g}$ of denatured DNA per ml) at $65^{\circ} \mathrm{C}$ for $4 \mathrm{~h}$, and hybridization was in fresh buffer, to which heatdenatured ${ }^{32}$ P-labeled D3-2 or D1-2 probe $\left(3 \times 10^{6} \mathrm{cpm}\right)$ had been added. Hybridization at $65^{\circ} \mathrm{C}$ for $2 \mathrm{~h}$ was followed by incubation at $40^{\circ} \mathrm{C}$ for $\approx 16 \mathrm{~h}$. The first washes were at low stringency in $3 \times$ $\mathrm{SSC}, 2.5 \% \mathrm{SDS}$ at $35^{\circ} \mathrm{C}$ for $15 \mathrm{~min}$ and then in $0.5 \times \mathrm{SSC}, 2.5 \%$ $\mathrm{SDS}$ at $35^{\circ} \mathrm{C}$ for $15 \mathrm{~min}$. Membranes were autoradiographed and washed under high-stringency conditions in $0.2 \times \mathrm{SSC}, 1 \% \mathrm{SDS}$ at $40^{\circ} \mathrm{C}$ for $15 \mathrm{~min}$ and then at $60^{\circ} \mathrm{C}$ for $15 \mathrm{~min}$ in the same buffer. Hybridization conditions with the CCCVd cRNA probe were as previously described (6). Autoradiography was done at $-80^{\circ} \mathrm{C}$ with an intensifying screen.

Reverse-transcription polymerase chain reaction (RT-PCR). For RT, $2 \mu \mathrm{l}$ of the nucleic acid extract was mixed with RT buffer (50 mM Tris [pH 8.8], $75 \mathrm{mM} \mathrm{KCl,} 3 \mathrm{mM} \mathrm{MgCl}_{2}$ ), $3.3 \mathrm{mM}$ dithiothreitol, $200 \mathrm{nM}$ antisense primer D1-2 or D3-2, and water to a final volume of $26 \mu \mathrm{l}$. This mixture was heated to $94^{\circ} \mathrm{C}$ for 4 min, chilled on ice, and 10 units of RNasin (Bresatec), $333 \mu \mathrm{M}$ dNTP mix (Promega, Madison, WI), and 400 units of MMLV-RT (GIBCO/BRL, Gaithersburg, MD) were added to a final volume of $30 \mu \mathrm{l}$. Incubation was at $50^{\circ} \mathrm{C}$ for $20 \mathrm{~min}$. The resulting firststrand cDNA was amplified by adding $5 \mu \mathrm{l}$ of the RT reaction mix to PCR buffer (final concentration of $10 \mathrm{mM} \mathrm{KCl}, 10 \mathrm{mM}$ $\left(\mathrm{NH}_{4}\right)_{2} \mathrm{SO}_{4}, 2 \mathrm{mM} \mathrm{MgSO}$, $20 \mathrm{mM}$ Tris [pH 8.8], 0.1\% Triton X100) containing $333 \mu \mathrm{M}$ dNTP mix, 2 units of Deep Vent polymerase (New England Biolabs Inc., Beverly, MA), $300 \mathrm{nM}$ each of antisense (D3-2 or D1-2) and sense primers (D4-2, residues 102 to $131 ; 5^{\prime}$-GTCGCCGATTCGTGCTGGTTGGGCTTCGTC-3') in a final volume of $30 \mu \mathrm{l}$, which was overlaid with mineral oil (Sigma Chemical Co., St. Louis). Amplification conditions were $94^{\circ} \mathrm{C}$ for $2 \mathrm{~min}, 70^{\circ} \mathrm{C}$ for $1 \mathrm{~min}$ and $94^{\circ} \mathrm{C}$ for $30 \mathrm{~s}$ for 5 cycles, $70^{\circ} \mathrm{C}$ for $30 \mathrm{~s}$ and $94^{\circ} \mathrm{C}$ for $30 \mathrm{~s}$ for 40 cycles, $72^{\circ} \mathrm{C}$ for $5 \mathrm{~min}$ and $25^{\circ} \mathrm{C}$ for 1 min for 1 cycle, using a Corbett FTS 320 thermal sequencer (Corbett Research, Mortlock, Australia).

\section{RESULTS}

Stages of tinangaja disease in coconut. Tinangaja disease was classified into early, middle, and late stages for this study (Table 1). At the early stage, the crown was slightly reduced in size (Table 1), as measured by the angle covered by the canopy when viewed horizontally (Fig. 1), and normal nuts were produced. At the middle stage, the crown was reduced, and nuts were small, elongated, and usually lacked a kernel (Fig. 1B). At the late stage, symptoms included small crown size, lack of nuts, thin leaflets, and gradually tapering trunk (Fig. 1C and D). Stipule retention (winging) and leaf stippling also were generally evident at the late stage. The palm samples and their assay results are provided in Table 1.

Nucleic acid fractionation and viroid detection by gel electrophoresis. Extracts from 15 coconut palms and a duplicate extract from 1 of these palms were fractionated on agarose gels to determine whether CTiVd could be detected. A typical result is shown in Figure 2A. The total amount of nucleic acid extracted from the leaf tissue varied for each sample but generally was repeatable for duplicate extractions and was greater for normal than for diseased palms. Extracts of palms 2, 4, 5, 6, and 10 showed a strong fluorescent band comigrating with the 142- to 154-bp DNA size markers (Fig. 2A), which was the same mobility as for the 246/247-nt CCCVd seen in extracts from the early stage of cadang-cadang infection of coconut from the Philippines (Fig. 2A) and was defined as the lower viroid region. Palm samples 1, 3, and 7 contained a heavy staining of nucleic acid over the viroid region that masked any viroid-like band. A weak band between the 220- and 295-bp DNA markers was sometimes observed in samples from Guam. This was the same mobility as for the CCCVd dimer. Agarose gel electrophoresis indicated that 8 of the 15 palms tested positive (Table 1). The assay could be completed in 1 day. The duplicate samples from palm 13 were both positive. 
Denaturing 2-D PAGE was used to examine samples that were positive based on agarose gel fractionation for the presence of the small circular molecules characteristic of a viroid. Figure 3A shows a brightly staining band from Guam sample 2, which ran just behind the diagonal in the second gel dimension. This mobility profile resembled that obtained for CCCVd. The CCCVd marker contained the monomeric $246 \mathrm{nt}$ form (Fig. 3B, arrow), the slower mobility $296 \mathrm{nt}$ form, and a small amount of highly retarded dimer viroid, which all fractionated behind the linear nucleic acid in the diagonal. This retardation is typical of a circular molecule. The band in Figure 3A was eluted from the gel, and probing by dot blot hybridization confirmed it was CTiVd.

Viroid detection by hybridization analysis. Nucleic acids fractionated in agarose gels were transferred by capillary blotting to nylon membranes for DOP hybridization. In a comparison of the oligonucleotide probes, D1-2 and D3-2 detected CTiVd, providing similar strength of signal, but D2-2, which bound adjacent to D1-2 on the viroid, hybridized only weakly (data not shown). The D3-2 probe was used routinely for hybridization assay (Figs. 2B and 4). The samples positive by staining in agarose gels (Fig. 2A) developed a strong hybridization signal for the CTiVd monomer (Fig. 2B) and a weaker signal for the CTiVd dimer. The dimer was detected in all CTiVd-positive samples, even though it was not readily evident in stained gels. The DOP-hybridization assay also detected a weak signal for the CTiVd monomer in sample 14 (data not shown), which previously had been scored as negative based on the gel staining technique (Table 1). Thus, hybridization analysis of the gel-fractionated samples with the CTiVd oligonucleotide probe found 9 positives of 15 palms tested (Table 1).

At high stringency, neither D3-2 nor D1-2 detected CCCVd in extracts from cadang-cadang-infected palms (Fig. 2B, lanes 1 and 3, and Fig. 4). Under low-stringency conditions, there was a very weak signal with CCCVd (data not shown) but no signal with healthy coconut palm extracts.

The specificity of DOP hybridization was demonstrated by sequentially probing one membrane first with a CTiVd-DOP (Fig. 4B) and then with a CCCVd-DOP (Fig. 4C). Coconut samples collected on Guam during a previous survey for $\mathrm{CCCVd}$ in the $\mathrm{Pa}-$ cific region, which were extracted, fractionated through polyacrylamide, transferred to membranes, and screened for viroid-like sequences with a full-length cRNA probe for CCCVd (6), were reexamined by DOP hybridization. In the original analysis with the CCCVd-cRNA probe at low stringency, the CCCVd marker lane (containing all monomer and dimer forms) developed a strong hybridization signal (Fig. 4A, lane Vd). Several of the samples from Guam showed a weak hybridization signal in the gel region near the bottom of the CCCVd monomers (Fig. 4A, lanes G1 and G4). At high stringency, the hybridization signal for these samples was lost, which suggests that none of them contained sequences closely related to CCCVd. After stripping the first probe, the membrane was reprobed at high stringency with the D3-2 DOP for CTiVd. There was no hybridization in the CCCVd marker lane, but there was strong hybridization in three samples, which indicated that monomeric CTiVd was present in the fractionated sample (Fig. 4B). In the reverse assay, DOP hybridization at high stringency with a probe (D1-1) specific for CCCVd (8) produced an intense signal in the $\mathrm{CCCVd}$ marker lane but no bands in the viroid region for the samples from Guam (Fig. 4C). Even at low stringency, there was no hybridization in Guam samples similar to that observed in Figure 4A (data not shown).

To analyze many samples, dot blot hybridization is more efficient than Northern blot hybridization. A dot blot assay of samples from coconuts grown in the Philippines and on Guam and of single samples from tomato infected with potato spindle tuber viroid (PSTVd), grapevine infected with several viroids of the apple scar skin viroid group, and avocado infected with avocado sunblotch viroid (ASBVd) is shown in Figure 4D. Extracts from Guam coconut samples are located in rows $\mathrm{U}$ through $\mathrm{X}$ (except for $\mathrm{X} 1$ and $\mathrm{X} 2$ ), and extracts from Philippine coconut samples are located in row Y (except Y1 and Y2). Of the viroid standards, only the CTiVd control dot, in template position Y1, was positive with DOP D3-2. Many extracts from Guam developed a positive signal after hybridization with DOP D3-2. None were positive with DOP D1-1, which was specific for CCCVd (data not shown). Some of the Philippine samples were positive with the D1-1 probe. DOP hybridization, therefore, can be used in place of Northern blot hybridization for specific detection of CTiVd. Using this approach, DOP hybridization identified 10 of the 15 Guam samples as positive for CTiVd. Sample 14 was confirmed as positive, and sample 9 was a weak positive. The absence of disease symptoms on palm 9 suggested that this palm was in the early stage of infection with CTiVd.

TABLE 1. Relationship between coconut tinangaja disease symptom expression in coconut palm and detection of coconut tinangaja viroid in coconut palm tissue

\begin{tabular}{|c|c|c|c|c|c|c|c|c|c|c|}
\hline \multirow[b]{2}{*}{ Sample } & \multicolumn{5}{|c|}{ Disease symptom } & \multirow[b]{2}{*}{$\begin{array}{c}\text { Disease } \\
\text { stage }^{\mathrm{d}}\end{array}$} & \multicolumn{4}{|c|}{ Viroid detection $^{\mathrm{a}}$} \\
\hline & Inflorescence & Fruit & Leaf $^{b}$ & $\begin{array}{c}\text { Crown } \\
\text { shape }\left(^{\circ}\right)\end{array}$ & Plant shape ${ }^{c}$ & & $\begin{array}{l}\text { Agarose gel } \\
\text { separation }\end{array}$ & $\begin{array}{l}\text { Northern } \\
\text { blot }^{\mathrm{e}}\end{array}$ & Dot blot & RT-PCR ${ }^{f}$ \\
\hline 1 & Normal & Normal & Normal & 360 & Normal & $\ldots$ & - & - & - & - \\
\hline 2 & Normal & $\begin{array}{l}\text { Deformed } \\
\quad \text { (elongated) }\end{array}$ & Stippl. & 180 & $\begin{array}{l}\text { Bent, taper., } \\
\text { stunted }\end{array}$ & MS & ++ & ++++ & ++++ & ++++ \\
\hline 3 & Normal & Normal & Normal & 180 & Normal & $\ldots$ & - & - & - & - \\
\hline 4 & Sterile & Absent & Wing. and stippl. & 90 & Taper. & LS & ++ & ++++ & ++++ & +++ \\
\hline 5 & Sterile & Absent & Wing. and stippl. & 90 & Taper. & LS & + & + & +++ & +++ \\
\hline 6 & Sterile & Absent & Wing. and stippl. & 90 & Taper., stunted & LS & ++ & +++ & ++ & ++++ \\
\hline 7 & Normal & Absent & Normal & 180 & Stunted & $\ldots$ & - & - & - & - \\
\hline 8 & Normal & Small & Normal & 270 & Taper. & MS & + & ++ & + & +++ \\
\hline 9 & Normal & Normal & Normal & 270 & Normal & ES & - & - & + & +++ \\
\hline 10 & Sterile & Absent & Wing. and stippl. & 90 & Taper. & LS & +++ & +++ & ++ & +++ \\
\hline 11 & Normal & Normal & Normal & 360 & Normal & $\ldots$ & - & - & - & - \\
\hline 12 & Sterile & Absent & Wing. and stippl. & 180 & Taper. & LS & +++ & ++++ & +++ & +++ \\
\hline $13 \mathrm{a}$ & Sterile & Absent & Wing. and stippl. & 90 & Taper. & LS & ++ & ++++ & +++ & ++++ \\
\hline $13 b$ & Sterile & Absent & Wing. and stippl. & 90 & Taper. & LS & ++ & +++ & + & ++++ \\
\hline 14 & Sterile & Absent & Wing. and stippl. & 180 & Taper. & LS & - & + & ++ & +++ \\
\hline 15 & Juvenile & Normal & Normal & 360 & Normal & $\ldots$ & - & - & - & - \\
\hline
\end{tabular}

a $-=$ viroid undetectable; + to $++++=$ viroid detectable with increasing relative strength of signal, respectively.

b Stippl. = stippling; wing. $=$ winging.

c Taper. $=$ tapering.

${ }^{\mathrm{d}} \mathrm{ES}, \mathrm{MS}$, and LS = early, middle, and late stages, respectively; ... = tinangaja absent.

e Membrane-based hybridization.

${ }^{\mathrm{f}}$ Reverse-transcription polymerase chain reaction. 


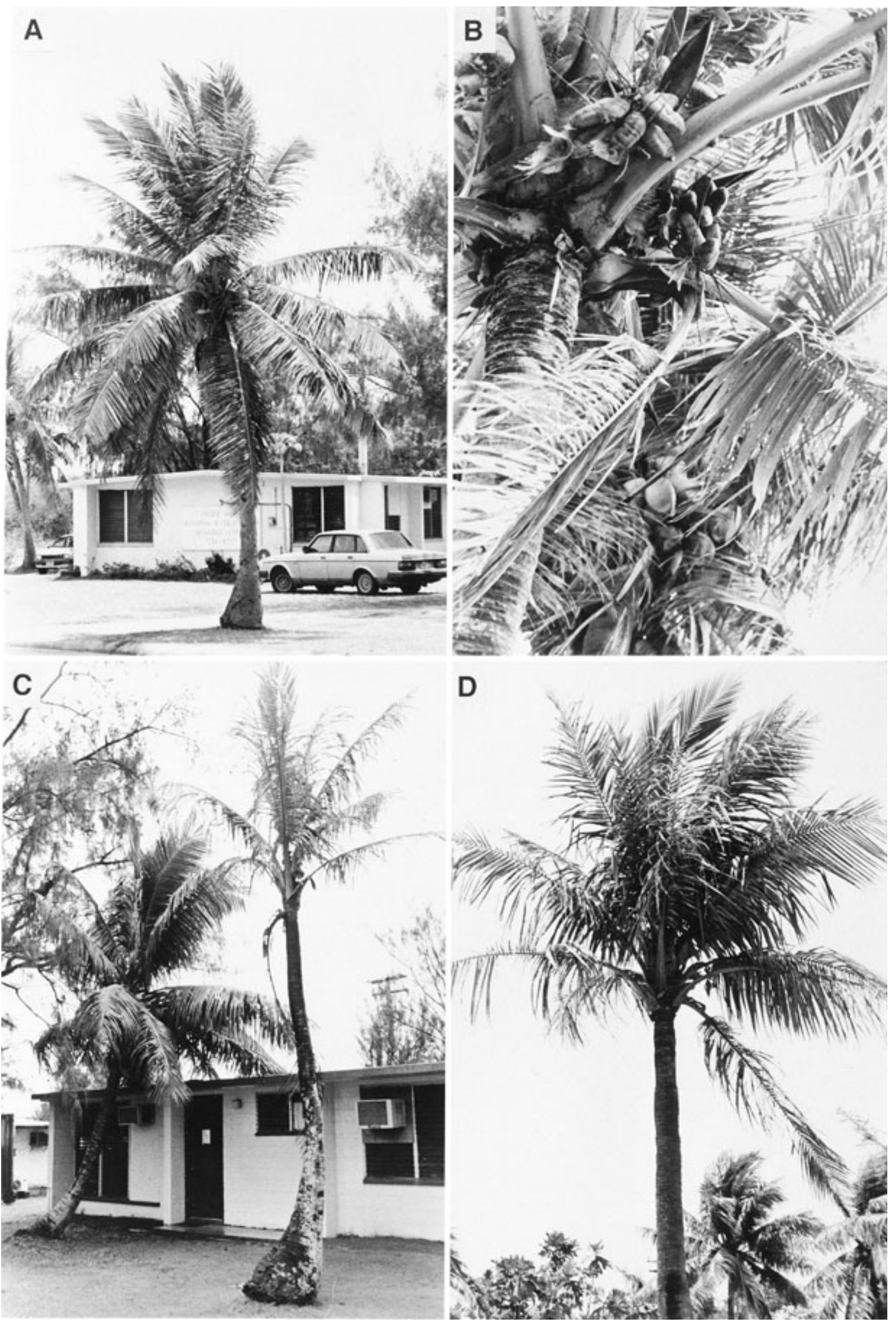

Fig. 1. Stages of tinangaja disease on coconut palms from Guam. A, Normal palm with full crown $\left(360^{\circ}\right)$. B, Deformed, narrow, elongated nuts associated with middle stage infection on palm sample 2 are visible in the foreground (compared to normal nut shape on palm sample 1). C, Early stage (left palm [sample 9], $270^{\circ}$ crown) and late stage (right palm [sample 10], $90^{\circ}$ crown and tapering trunk) infections in palm. D, Late stage infection in palm sample 12 with reduced crown $\left(180^{\circ}\right)$, gradually tapering trunk, and lack of nuts. Samples are listed in Table 1. 
Viroid detection by RT-PCR. Detection of CTiVd by RT-PCR was tested with the DOPs as antisense primers for all samples. The effect of different primer combinations on the amplification of products from a known CTiVd extract was used to standardize the procedure and to confirm the specificity of the primers for CTiVd (Fig. 5). The combination of D1-2 for antisense cDNA synthesis and D1-2 with D4-2 as the primer pair for PCR provided amplification of a full-length CTiVd of $254 \mathrm{bp}$, as expected. Using D3-2 for antisense cDNA synthesis and D3-2 with D4-2 for PCR, a 138-bp fragment was produced. Using D1-2 as antisense primer for RT and then PCR in a multiplex assay with D1-2, D3-2, and D4-2, the expected 254- and 138-bp products were produced (Fig. $5)$. However, an additional unidentified product of $\approx 210 \mathrm{bp}$ also was consistently amplified. CCCVd was amplified by RT-PCR with a different set of specific primers (Fig. 5). No product was obtained when the CCCVd antisense cDNA from the sample used in Figure 5, lane 4, was subjected to PCR with the CTiVd primers (Fig. 5, lane 5) nor from an extract from healthy coconut when

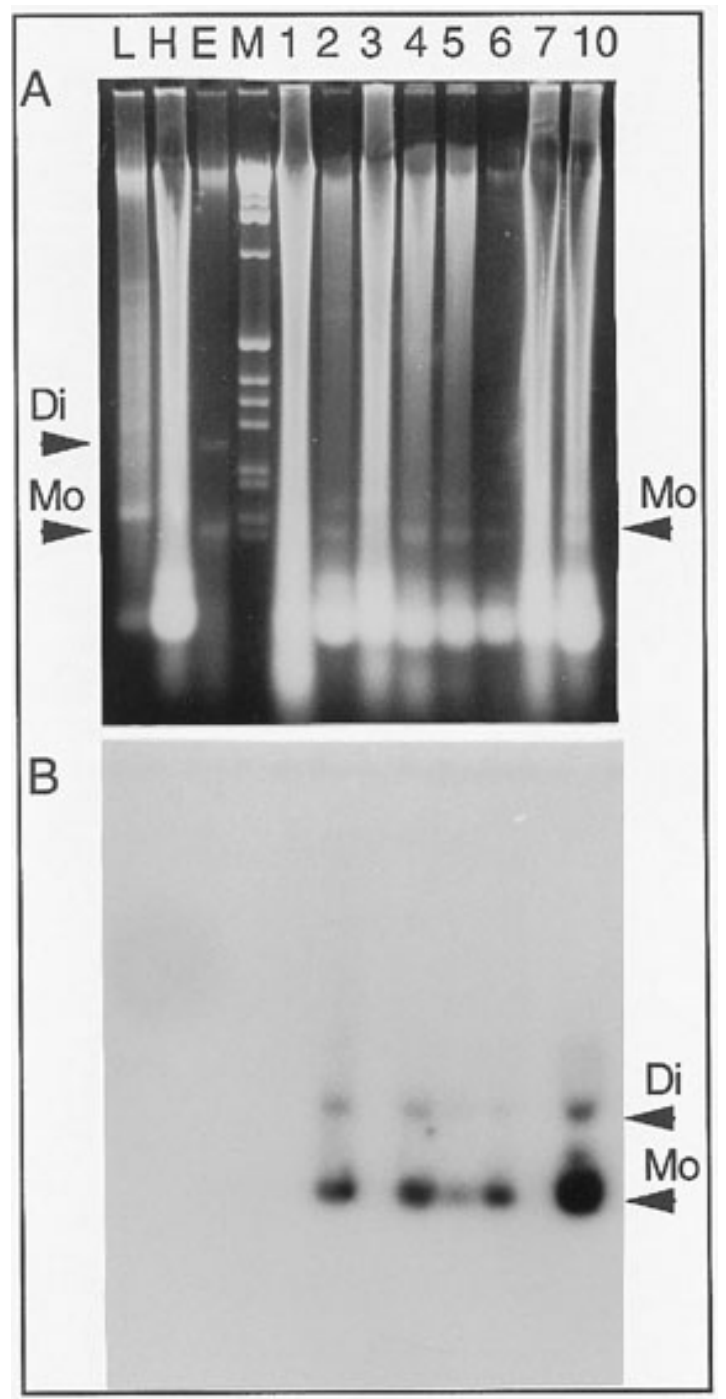

Fig. 2. Agarose gel fractionation of nucleic acids from tinangaja-affected coconuts and Northern blot for coconut tinangaja viroid (CTiVd) detection. A, Gel showing mobility of ethidium bromide-stained nucleic acid from Guam coconut samples relative to the mobility of the coconut cadang-cadang viroid (CCCVd) monomer 246-nucleotide (nt) form and DNA size markers. B, Autoradiograph after diagnostic oligonucleotide-probe (DOP) hybridization assay with probe D3-2 and high-stringency washes. Samples per lane from left, late stage CCCVd-infected (L, 296-nt form), healthy (H), and early stage CCCVdinfected coconut (E, 246-nt form). Samples 1, 2, 3, 4, 5, 6, 7, and 10 from Guam are described in Table 1. The positions of monomeric (Mo) and dimeric (Di) early stage CCCVd markers are indicated to the left; the CTiVd monomer and dimer are indicated to the right. Lane M, 1-kb ladder (GIBCO-BRL). using CTiVd primers (Fig. 5, lane 6). In contrast, RT-PCR of three of the Guam samples amplified $\approx 140$-bp fragments, which is characteristic of CTiVd. Only the expected fragments were amplified by RT-PCR. In one sample, Guam palm 2, multiple products were observed at $\approx 390$ and $650 \mathrm{bp}$, with one weak additional larger fragment. These sizes were equivalent to the addition of a monomer, dimer, and trimer of the viroid to the 140-bp fragment. Of the 15 Guam palm samples examined, 10 were scored as positive (Table 1). All the samples previously scored as positive in other tests were strongly positive by RT-PCR. There was little difference in the intensity of the CTiVd-positive RT-PCR products in stained gels compared with the variation seen for the DOP-hybridization signals (Table 1). Samples that showed no RT-PCR products in stained gels were not assayed by hybridization to test for low concentrations of PCR products.

Correlation between disease symptoms and molecular detection of CTiVd. Tinangaja disease is currently indexed by scoring the number of specific symptoms present on a palm (Table 1). In every case in which palms had clear disease symptoms, CTiVd was detected by molecular techniques. CTiVd also was detected in palm 9, which appeared healthy and was growing next to the strongly positive palm 10 (Fig. 1B). This suggests that palm 9 was at the early stage of infection. Likewise, palm 14, which was negative based on staining of agarose gel fractionation of nucleic acids, was positive based on DOP-hybridization and RT-PCR assays. Palm 1, which was growing next to the strongly positive palm 2 (Fig. 1C), had no detectable viroid and was considered healthy.

Thus, agarose gels alone can be used to confirm CTiVd infection in coconut palms that show apparent symptoms of tinangaja disease. The absence of the characteristic viroid fragment in gels from extracts of palms with apparent disease symptoms could in-

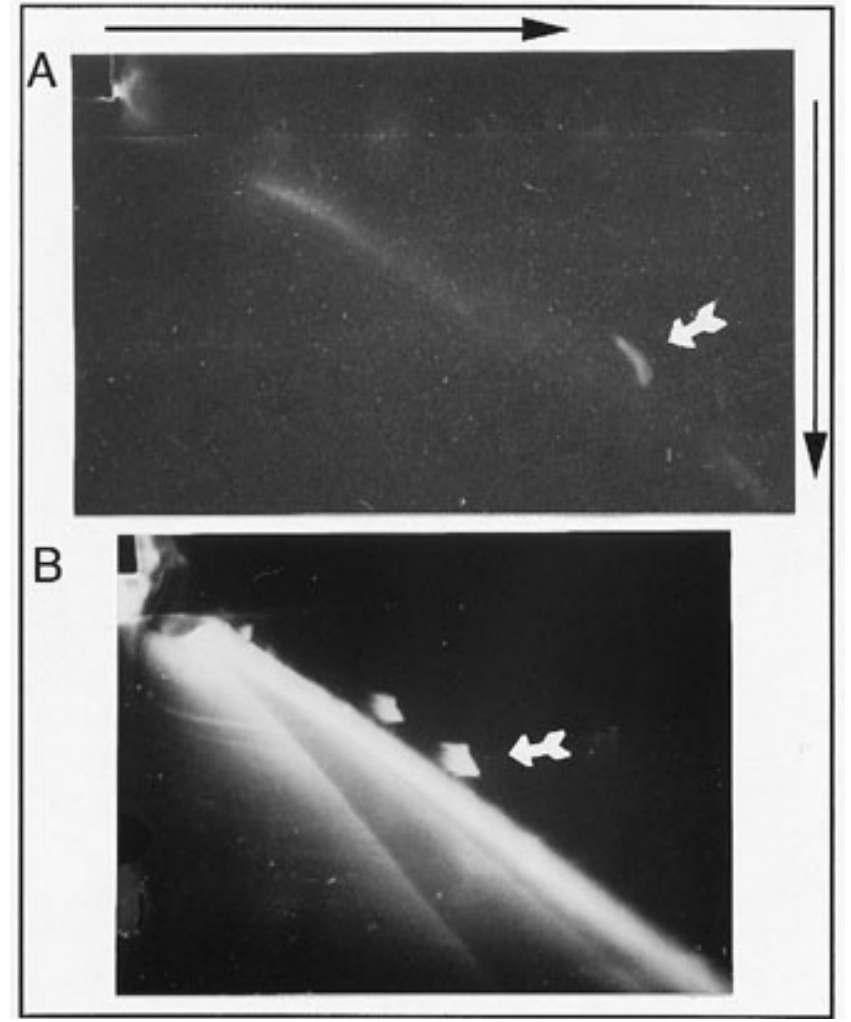

Fig. 3. Two-dimensional gel fractionation of nucleic acid from tinangaja- and cadang-cadang-affected coconut palms from Guam. A, Extract from middle stage tinangaja-diseased coconut sample 2 (described in Table 1) and B, coconut cadang-cadang viroid (CCCVd) marker composite of 296- and 246-nucleotide (nt) forms from cadang-cadang-affected coconut palms. The first dimension was from left to right; the second dimension was from top to bottom. The coconut tinangaja viroid and CCCVd $246 \mathrm{nt}$ are indicated with arrows (described in text). 
dicate that the abnormal phenotype is caused by something other than CTiVd. However, to reliably detect the low level of CTiVd at the early infection stage, and to distinguish it from CCCVd infection, molecular-based DOP hybridization or RT-PCR is required.

\section{DISCUSSION}

Rapid indexing of pathogens in coconuts ultimately needs to be performed in coconut-growing countries. Many of these countries overcome limitations of financial support, equipment, technology, and personnel by establishing interactive programs with special-

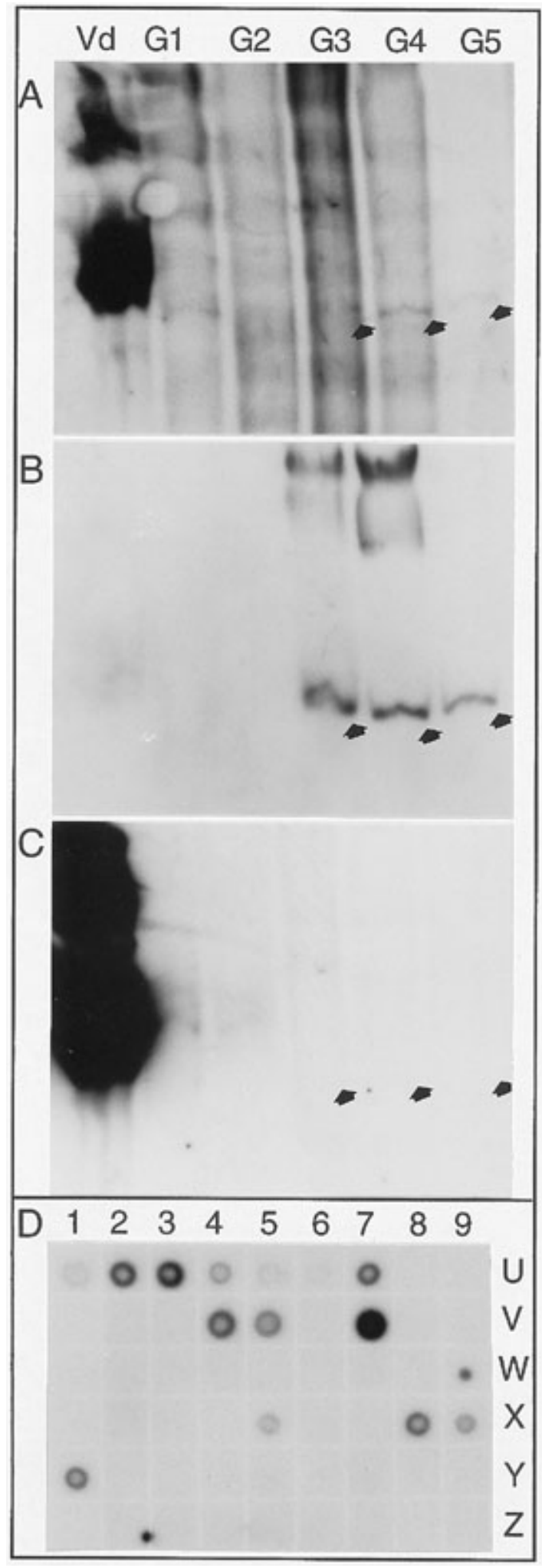

ized laboratories to develop indexing procedures for coconut pathogens. A major objective of the current project was to develop a nucleic acid extraction and fractionation method requiring relatively low technology for the initial indexing of coconut palms for a viroid, namely CTiVd, in field-grown palms on the island of Guam. The additional, more specific and sensitive testing with a smaller number of samples could be done in a collaborating laboratory, with the long-term objective of transferring such technology to key indexing laboratories in coconut-growing countries. Such an objective would reduce the risk associated with moving possibly infected plant material between countries.

The system described in this paper was developed because disease symptoms are unreliable indicators for identifying tinangajaaffected coconut palms, especially for identifying palms in the early disease stage. For example, several coconut palms observed in the Philippines with the elongated nut shape associated with CTiVd infection were not positive for CTiVd or CCCVd (R. A. J. Hodgson, unpublished data), and tinangaja, like cadang-cadang, probably has an early asymptomatic stage that may last for several years. Viroid detection, therefore, is the only suitable indicator of infection for studying viroid epidemics. PAGE fractionation can be used to identify either CTiVd or CCCVd and is used routinely in the Philippines for CCCVd (9). This is a relatively labor-intensive procedure, however. The simple and quick agarose gelbased fractionation of nucleic acids described here (Fig. 2), which uses commercially available DNA size standards as a mobility reference for the viroids, allowed palms suspected of expressing symptoms of tinangaja to be confirmed as containing CTiVd. Samples that were positive in the first assay required no further testing, whereas the negative samples required the more sensitive molecular hybridization or RT-PCR assay. Thus, a reduced number of samples required the more expensive and complex viroid indexing assay.

The molecular hybridization assay previously used for coconut viroids and viroid-like RNAs (6) required extraction of samples by the polyethylene glycol precipitation procedure, fractionation on large-format $20 \%$ polyacrylamide gels, and probing with a radioactive cRNA. Relatively small numbers of samples could be handled, and the test was cumbersome, relatively expensive, and required several weeks to obtain the result. Moreover, synthesis of the probe could be done only in a specialized laboratory, was susceptible to RNase digestion, and resolution of the gel fractionation was poor (Fig. 4A).

In contrast, the agarose gel fractionation procedure described here removed many of these disadvantages (Fig. 2B). Fifteen samples could be processed and fractionated, and the initial indexing could be recorded in 1 day by one person. Nucleic acid transfer to membranes was overnight, with hybridization analysis taking another 1 to 2 days. Scaling up of gel size increased throughput, so 180 samples could be fractionated and blotted to membranes each day. Alternatively, up to 1,000 samples could be ap-

Fig. 4. Specificity of diagnostic oligonucleotide-probe (DOP) hybridization assay for coconut tinangaja viroid (CTiVd) detection. Northern blot containing marker coconut cadang-cadang viroid (CCCVd) and Guam palm samples were sequentially probed with $\mathbf{A}$, a CCCVd cRNA probe at low stringency; B, CTiVd DOP D3-2 at high stringency; and C, CCCVd DOP D1-1 at high stringency. D, Dot blot assays for CTiVd with DOP D3-2 at high stringency. A through C, Vd is a CCCVd marker viroid mix of the four monomers (247, 246, 297 and 296 nucleotides) and their dimers; the remaining lanes contain nucleic acid extracted from five coconut palms on Guam in 1991. Arrows show the location of monomeric CTiVd. For the dot blot assay (D), samples were healthy coconut (X1); CCCVd (X2); CTiVd (Y1); tomato with potato spindle tuber viroid (Y2); grapevine with mixed viroids (Z1); avocado with avocado sunblotch viroid (Z2); CCCVd dilutions of $1 / 10,1 / 100,1 / 1,000,1 / 5,000$, and 0 concentration (Z5, Z6, Z7, Z8, and Z9, respectively); and coconut samples from the Philippines ( $\mathrm{Y} 3$ to $\mathrm{Y} 9$ ) and Guam (rows U, V, and $\mathrm{W}$ and $\mathrm{X} 3$ to X9). No samples are in coordinates Z3 and Z4. 
plied as dot blots. The limiting factor was obtaining the nucleic acid extracts from many samples-approximately 150 extracts per person per week can be conveniently produced. The bag extraction method, which is now routinely used in our laboratory for extracting slurry from palm leaf samples, provides many advantages. It is versatile, contamination is low, and the final nucleic acid extract can be stored at $-20^{\circ} \mathrm{C}$ for several months without deterioration, allowing time for accumulation of samples from multiple collections and extractions. Hybridization with an endlabeled radioactive DOP provided selective and reliable detection of viroid in samples in which viroid had not been detected previously. Other advantages include easy labeling of probes that can be synthesized in large amounts and used for both DOP hybridization and RT-PCR. Nonradioactive labels, such as biotin, digoxigenin (DIG), or fluorophores, can be incorporated during the synthesis of DOPs, converting the procedure into a nonradioactive detection system. The DIG-labeled oligonucleotide system has been applied for the detection of both CTiVd and CCCVd (J. W. Randles, unpublished data).

Selection of a unique sequence for the DOP allows it to be specific for a particular coconut viroid. This may be useful for quarantine purposes, when it is necessary to know whether a listed viroid pathogen is present $(3,5)$. We have shown that DOPs can discriminate between the related $\mathrm{CTiVd}$ and $\mathrm{CCCVd}$ (Figs. 2B and 4). Because of the discriminating ability of DOPs, in many cases it will not be necessary to first fractionate extracts of samples by gel electrophoresis. Using DOP hybridization in a dot blot format, two or three probes, each specific for a given viroid, can be used sequentially to indicate which viroid is present and to confirm the identity of the viroid. We currently use two DOPs for CTiVd, D1-2 and D3-2, and have others for CCCVd (8). With the dot blot format, DOP hybridization can assay several thousand samples in one experiment.

The DOPs also can be used as primers for RT-PCR. The primer set used to amplify the CTiVd full-length 254-bp product gave less reproducible results than the primer pair that amplified the partiallength 138-bp fragment (data not shown). Thus, to test for the presence of CTiVd, the primer pair of D3-2 with D4-2 was used. All positive coconut palms from Guam had the expected 140-bp fragment, and one sample (Guam 2) also produced fragments with sizes representing multimeric forms of the viroid. This latter case may be due to multimeric forms of the viroid occurring in the host. Dimers of CTiVd were detected by hybridization in most of the positive samples (Fig. 2B), and samples contained a circular molecule (Fig. 3), which hybridized with the diagnostic probe for CTiVd.

The procedure finally adopted for indexing coconuts for CTiVd will depend on factors such as required detection sensitivity, number of samples to be examined, and availability of facilities. If characteristic symptoms of disease are evident, then an easy, reliable, and quick assessment by agarose gel fractionation of nucleic acid extracts can be done. Conversely, if symptoms are not present or are not characteristic, a molecular assay is needed. Although RTPCR is applicable, it is relatively expensive and can be prone to reaction errors. The DOP-hybridization assay is more robust and allows throughput of large sample numbers at a relatively low cost. The disadvantage, currently, is that DOP hybridization utilizes radioactive probes. Nonradioactive probes are being investigated for future use.

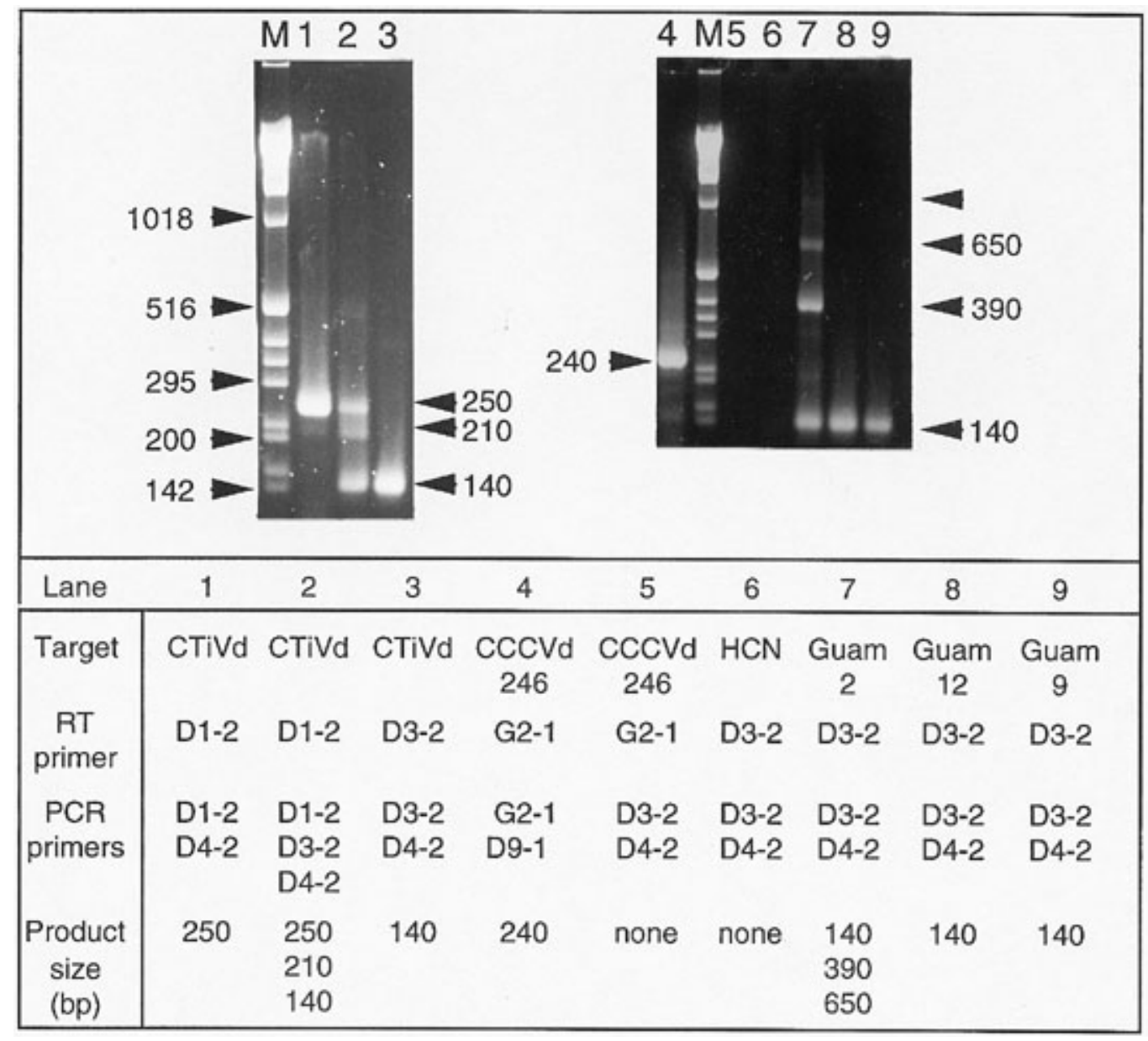

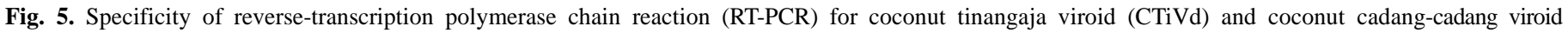

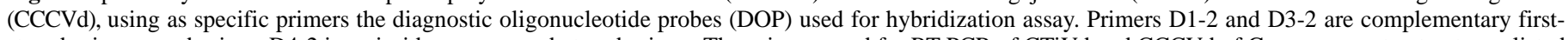

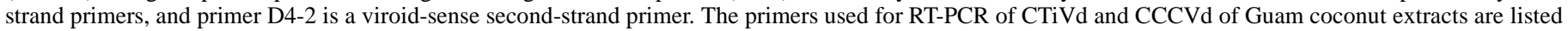
in the bottom panel. $\mathrm{HCN}=$ healthy coconut, G2-1 and D9-1 are CCCVd primers, and lane M is the 1-kb ladder (GIBCO-BRL). 


\section{ACKNOWLEDGMENTS}

This work was supported by Australian Research Council grant A09531894. We thank D. Hanold and H. Bogacz for the original Northern blot used in Figure 4, R. Bonfiglioli for PSTVd-infected tomato, Yan Fong Chow Wah for viroid-infected grapevine, R. H. Symons for ASBVd-infected avocado, and the Australian Centre for International Agricultural Research for earlier funding of coconut viroid research.

\section{LITERATURE CITED}

1. Boccardo, G. 1985. Viroid etiology of tinangaja and its relationship with cadang-cadang disease of coconut. Pages 75-99 in: Subviral Pathogens of Plants and Animals: Viroids and Prions. K. Maramorosch and J. J. McKelvey, Jr., eds. Academic Press, Orlando, FL.

2. Boccardo, G., Beaver, R. G., Randles, J. W., and Imperial, J. S. 1981. Tinangaja and bristle top, coconut diseases of uncertain etiology in Guam, and their relationship to cadang-cadang disease of coconut in the Philippines. Phytopathology 71:1104-1107.

3. Fassil, H., and Diekman, M. 1995. Safe movement of coconut germplasm and coconut cadang-cadang viroid-related sequences. Plant Genet. Resources Newsl. 104:29-30.

4. Feldstein, P. A., Levy, L., Randles, J. W., and Owens, R. A. 1997. Synthesis and two-dimensional electrophoretic analysis of mixed populations of circular and linear RNAs. Nucleic Acids Res. 25:4850-4854.

5. Frison, E. A., Putter, C. A. J., and Diekman, M., eds. 1993 FAO/IBPGR Technical Guidelines for the Safe Movement of Coconut Germplasm. Food and Agriculture Organization of the United Nations/International Board for Plant Genetic Resources, Rome.

6. Hanold, D., and Randles, J. W. 1991. Detection of coconut cadangcadang viroid-like sequences in oil and coconut palm and other monocotyledons in the south-west Pacific. Ann. Appl. Biol. 118:139-151.

7. Haseloff, J., Mohamed, N. A., and Symons, R. H. 1982. Viroid RNAs of cadang-cadang disease of coconuts. Nature (Lond.) 299:316-321.
8. Hodgson, R. A. J., and Randles, J. W. 1997. Diagnostic oligonucleotideprobe (DOP) hybridization to detect coconut cadang-cadang viroid. Pages 25-29 in: Proc. Workshop Viroid-like Sequences Coconut. International Plant Genetic Resources Institute, Rome.

9. Imperial, J. S., Bautista, R. M., and Randles, J. W. 1985. Transmission of the coconut cadang-cadang viroid to six species of palm by inoculation with nucleic acid extracts. Plant Pathol. 34:391-401.

10. Keese, P., Osorio-Keese, M. E., and Symons, R. H. 1988. Coconut tinangaja viroid: Sequence homology with coconut cadang-cadang viroid and other potato spindle tuber viroid related RNAs. Virology 162:508-510.

11. Koltunow, A., and Rezaian, M. A. 1989. A scheme for viroid classification. Intervirology 30:194-201.

12. Randles, J. W. 1975. Association of two ribonucleic acid species with cadang-cadang disease of coconut palm. Phytopathology 65:163-167.

13. Randles, J. W., Boccardo, G., and Imperial, J. S. 1980. Detection of the cadang-cadang associated RNA in African oil palm and buri palm. Phytopathology 70:185-189.

14. Randles, J. W., Boccardo, G., Retuerma, M. L., and Rillo, E. P. 1977. Transmission of the RNA species associated with cadang-cadang of coconut palm, and the insensitivity of the disease to antibiotics. Phytopathology 67:1211-1216.

15. Randles, J. W., Hodgson, R. A. J., and Wefels, E. 1996. The rapid and sensitive detection of plant pathogens by molecular methods. Australas. Plant Pathol. 25:71-85.

16. Randles, J. W., Miller, D. C., Morin, J. P., Rohde, W., and Hanold, D. 1992. Localisation of coconut foliar decay virus in coconut palm. Ann. Appl. Biol. 121:601-617.

17. Sambrook, J., Fritsch, C., and Maniatis, T. 1989. Molecular Cloning: A Laboratory Manual. 2nd ed. Cold Spring Harbor Laboratory Press, Cold Spring Harbor, NY.

18. Wall, G. C., and Wiecko, A. T. 1997. Survey of Tinangaja on Guam's coconut population. Phytopathology 87 (Suppl.):S101.

19. Weston, W. H. 1918. Report on the plant disease situation in Guam. Pages 45-62 in: Guam Agricultural Experimental Station Report for 1917. Guam Agricultural Experimental Station 